\title{
Thermoanalytical and Solution Stability Studies of Hexamethylenedithiocarbamates
}

\author{
Valéria D. Benedini, ${ }^{a}$ Patrícia A. Antunes, ${ }^{b}$ Éder T. G. Cavalheiro ${ }^{*, a}$ and Gilberto O. Chierice ${ }^{a}$ \\ ${ }^{a}$ Instituto de Química de São Carlos, Universidade de São Paulo, CP 780, 13560-970 São Carlos-SP, Brazil \\ ${ }^{b}$ Universidade do Oeste Paulista, Rua José Bongiovani, 700, 19050-680 Presidente Prudente-SP, Brazil
}

\begin{abstract}
Estudos termogravimétricos e calorimétricos exploratórios diferenciais de hexametilenoditiocarbamatos de níquel(II), cobre(II), zinco(II) e cádmio(II) foram realizados sob atmosferas dinâmicas de ar e nitrogênio, para avaliar as etapas e os produtos de decomposição térmica. Esses produtos, quando cristalinos, foram caracterizados por difratometria de raios $\mathrm{X}$, sendo predominantemente constituídos por sulfetos e óxidos metálicos sob $\mathrm{N}_{2}$ e ar, respectivamente. Usando espectrofotometria na região do ultravioleta, também foram determinados o $\mathrm{pK}_{\mathrm{a}}=3,6$ $\pm 0,2$ para o ácido hexametilenoditiocarbâmico em força iônica igual a $0,50 \mathrm{~mol} \mathrm{dm}^{-3}(\mathrm{KCl}) \mathrm{a}$ $25,0{ }^{\circ} \mathrm{C}$ e os parâmetros cinéticos de decomposição em diferentes valores de $\mathrm{pH}\left(\mathrm{k}_{\mathrm{lim}}=2,21 \times\right.$ $\left.10^{-2} \mathrm{~s}^{-1} \mathrm{e} \mathrm{t}_{1 / 2 \lim }=156 \mathrm{~s}\right)$.
\end{abstract}

Thermogravimetric and differential scanning calorimetric investigation of the thermal behavior of nickel(II), copper(II), zinc(II) and cadmium(II) hexamethylenedithiocarbamates were performed under nitrogen and air atmospheres in order to investigate the steps and products of thermal decomposition. When obtained in a crystalline form, the decomposition products were identified by their X-ray diffraction patterns. Metal sulfides and oxides were the major residues under nitrogen and air atmospheres, respectively. Spectrophotometric measurements in the ultraviolet region were used to estimate the $\mathrm{pK}_{\mathrm{a}}=3.6 \pm 0.2$ for the haxamethylenedithiocarbamic acid at 0.50 mol dm${ }^{-3}$ ionic strength $(\mathrm{KCl})$ at $25.0{ }^{\circ} \mathrm{C}$ and the kinetic parameters of decomposition at different $\mathrm{pH}$ values $\left(\mathrm{k}_{\lim }=2.21 \times 10^{-2} \mathrm{~s}^{-1}\right.$ and $\left.\mathrm{t}_{1 / 2 \lim }=156 \mathrm{~s}\right)$.

Keywords: hexamethylenedithiocarbamate, thermogravimetry, differential scanning calorimetry, decomposition rate constant

\section{Introduction}

Dithiocarbamates (DTC) are products of the reaction between a primary or secondary amine and carbon dissulfide in basic media. Their versatility and applicability was discussed by Kitson. ${ }^{1}$ The interest in the solution stability of dithiocarbamates has been renewed by the utilization of such compounds as coadjutants in the treatment of AIDS, ${ }^{2,3}$ but they have also been suggested for tuberculosis ${ }^{4}$ and cancer $^{5}$ treatment in the past. These applications demand enough chemical stability for an effective action in the biological medium.

The applications of this class of compounds are not limited to medicine and their use in agriculture, industry, analytical and organic chemistry, as well as their physicochemical properties, are summarized in several

*e-mail: cavalheiro@iqsc.usp.br review articles. ${ }^{6-15}$ From these works it is known that dithiocarbamates obtained from cyclic amines are more stable than the aliphatic derivatives.

The stability of dithiocarbamates in solution is strongly dependent on the $\mathrm{pH}$, as discussed by several authors. ${ }^{16-22}$ However, it was the work of Chakrabarti and co-workers ${ }^{19-22}$ that led to the proposition of a decomposition intermediate whose stability is related to the presence of a water molecule in its structure.

Considering that the decomposition of dithiocarbamates is very fast in acidic media, a spectrophotometric method based on diode-array measurements has been proposed ${ }^{23}$ in order to reach a more accurate determination of the $\mathrm{pK}_{\mathrm{a}}$ of dithiocarbamic acids. A correlation between the infrared spectroscopy data of the coordination nature of cyclic DTC complexes and its effect on the thermal decomposition of such compounds has also been presented. ${ }^{24,25}$

Hexamethylenedithiocarbamate (hex) is a cyclic DTC derived from hexamethyleneimine (homopiperidine), a 
seven member heterocyclic amine, whose structure is represented in Figure 1.

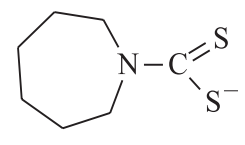

Figure 1. Structure of the hexamethylenedithiocarbamate.

Among many other applications, hex complexes have widely been used in the determination of several metals using different strategies and techniques for preconcentration. Examples of such applications, presented during the last 35 years, include the recent description of the profitable use of $\mathrm{Co}(\text { hex })_{3},{ }^{26-33} \mathrm{Fe}(\text { hex })_{3}{ }^{33-37}$ and its mixtures with $\mathrm{Fe}_{2} \mathrm{O}_{3} \cdot \mathrm{xH}_{2} \mathrm{O}^{38-42}$ and $\mathrm{Pb}$ (hex) ${ }_{2}^{43-46}$ as a colloidal precipitate collector in the flotation preconcentration of $\mathrm{Cd}$, $\mathrm{Cu}, \mathrm{Fe}, \mathrm{Ni}, \mathrm{Pb}, \mathrm{Zn}, \mathrm{Tl}, \mathrm{Cr}$ and $\mathrm{Mn}$, allowing determinations at the $n g \mathrm{dm}^{-3}$ range in several water samples.

These complexes have also been used to pre-concentrate metal ions in columns. After this step, the complexes are eluted and inserted in HPLC systems, allowing separations and simultaneous quantifications. ${ }^{47-52}$ They have also been employed in separation and co-precipitation ${ }^{53-60}$ and in the less recent applications with solid ${ }^{61-64}$ and liquid phase extractions ${ }^{65-75}$ followed by determination by atomic spectroscopic techniques of several elements.

Studies regarding the standard enthalpy of formation of hexamethyleneaminium hexamethylenedithiocarbamate, ${ }^{76}$ dye-sensitized photolysis ${ }^{77-79}$ and crystal structures of ligand and complexes ${ }^{80,81}$ can also be found.

Thermal analysis of mixed-ligand nickel hexamethylenedithiocarbamate complexes with triphenyl and tributylphosphine, ${ }^{82}$ as well as of lanthanide complexes with hexamethylenedithiocarbamate, ${ }^{83,84}$ have been described. Recently, the thermal behavior of the ammonium and hexamethyleneaminium salts of hexamethylenedithiocarbamate was also reported. ${ }^{85}$

The solution stability of the hexamethylenedithiocarbamate proved to be important in medical applications. A representative example is the patent presented by the French Roussel-Uclaf company ${ }^{86}$ regarding the use of this DTC as a protector of hepatic cells. The compound is taken orally or by a bloodshot as an alkaline cation salt solution. In addition, the thermal behavior is another important feature in industrial and agricultural application of this dithiocarbamate, as related to thermal stability and residues generated during thermal decomposition. $^{7}$

Despite the importance of the solution and thermal stability for hex applications, few studies regarding these issues have been reported. In the present work, the $\mathrm{pK}_{\mathrm{a}}$ value of the hexamethylenedithiocarbamic acid (Hhex) was determined in ionic strength $\mathrm{I}=0.50 \mathrm{~mol} \mathrm{dm}{ }^{-3}$ by spectrophotometry in the ultraviolet region, and used to estimate the decomposition rate of hexamethylenedithiocarbamate (hex) at different $\mathrm{pH}$ values using a method based on diode-array measurements of the absorbance. ${ }^{23}$ Additionally, the thermal behavior of $\mathrm{M}(\mathrm{hex})_{2}(\mathrm{M}=$ nickel(II), copper(II), zinc(II) and cadmium(II)) solid state complexes was evaluated, as these compounds are important examples of hex complexes with industrial and agricultural applications.

\section{Experimental}

All reagents were of analytical grade and used without further purification. The water employed in all experiments was deionized before use.

\section{Hexamethyleneaminium-hexamethylenedithiocarbamate (HMA-hex) - synthesis and characterization}

The HMA-hex salt was obtained by dissolving $0.4 \mathrm{~mol}$ of hexamethyleneimine in $50 \mathrm{dm}^{3}$ of ethanol/water $1: 1$ $(\mathrm{v} / \mathrm{v})$ in an erlenmeyer. The mixture was kept in an ice bath and protected from the light. Nitrogen was bubbled into the solution for $5 \mathrm{~min}$ and then $0.2 \mathrm{~mol}$ of carbon disulfide was slowly added to the reaction mixture. The white solid thus obtained was filtered, washed with cold ethanol and then dissolved in a minimum amount of ethanol/water 1:1 (v/v) at $35{ }^{\circ} \mathrm{C}$, protected from the light. The solution was frozen and the white needle-like crystals were dried in a vacuum oven at $35^{\circ} \mathrm{C}$ for $8 \mathrm{~h}$ and characterized as:

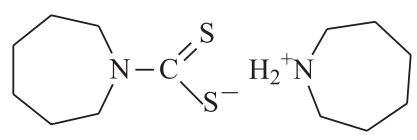

Hexamethylenedithiocarbamate complexes - synthesis and characterization

The metal complexes were obtained by direct reaction of the HMA-hex solution and $\mathrm{CdCl}_{2} \cdot 2 \mathrm{H}_{2} \mathrm{O}, \mathrm{CuCl}_{2} \cdot \mathrm{H}_{2} \mathrm{O}$, $\mathrm{NiCl}_{2} \cdot 6 \mathrm{H}_{2} \mathrm{O}$ and $\mathrm{ZnCl}_{2}$ solutions in a glove bag (ColeParmer, USA) under $\mathrm{N}_{2}$. The resulting precipitates, with characteristic colors, were filtered off, washed with water and then with ethanol. They were finally dried in a vacuum oven at $35{ }^{\circ} \mathrm{C}$ for $8 \mathrm{~h}$ and characterized as:

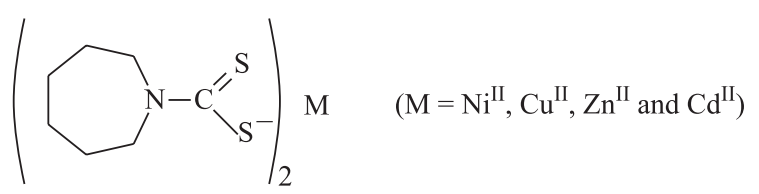




\section{Buffer solutions}

The McIlvaine buffer solutions with ionic strength adjusted to $0.50 \mathrm{~mol} \mathrm{dm}^{-3}(\mathrm{KCl})$ were prepared according to the procedure described by Elving et al. ${ }^{87}$ The $\mathrm{pH}$ values of these buffers were accurately measured with a glass electrode previously calibrated with $\mathrm{KCl}$ solutions of ionic strength $0.50 \mathrm{~mol} \mathrm{dm}^{-3}$ and hydrogen ion concentration 1.00 $\times 10^{-2}$ and $1.00 \times 10^{-4} \mathrm{~mol} \mathrm{dm}^{-3}\left(\mathrm{HClO}_{4}\right)$, corresponding to $\mathrm{pH} 2.00$ and 4.00 , respectively. ${ }^{88}$

\section{Equipment}

The characterization of the complexes was performed by IR vibrational spectroscopy (KBr pellets) in a Nicolet 5SXC spectrophotometer. Flame atomic absorption spectroscopy was carried out in a Hitachi Z-8100 spectrophotometer and $\mathrm{C}, \mathrm{N}, \mathrm{H}$ contents were determined by elemental analysis using a Fisons EA 1108 CNHS-O instrument.

Thermogravimetric (TG) curves were recorded in a DuPont 9900 thermoanalyser coupled with a TGA 951 Thermogravimetric Module, under a gas flow of $90 \mathrm{dm}^{3}$ $\min ^{-1}\left(\mathrm{~N}_{2}\right.$ or air) in a platinum crucible. A heating rate of $10{ }^{\circ} \mathrm{C} \mathrm{m^{-1 }}$ and samples of about $7 \mathrm{mg}$ at atmospheric pressure were employed. The differential scanning calorimetric (DSC) curves were recorded in a DuPont 9900 thermoanalyser coupled with a DSC 910 Calorimetric Module under a gas flow of $90 \mathrm{dm}^{3} \min ^{-1}\left(\mathrm{~N}_{2}\right.$ or air), in covered aluminum pans with a central pin hole, at a heating rate of $10{ }^{\circ} \mathrm{C} \mathrm{min}-1$ and using samples of about 5 $\mathrm{mg}$ at atmospheric pressure. The cell was previously calibrated for temperature and energy $(\Delta H)$ using indium metal $(99.9+\%)$ as standard.

Intermediates of the thermal decomposition process were generated in an oven at the same temperature and atmosphere in which they appeared in the TG curves. After 15 min of heating, they were cooled down and kept in a desiccator under vacuum. The X-ray patterns of the crystalline residues were recorded in a VEB-Karl Zeiss Jena URD6 diffractometer. The results were compared with standard data from the International Centre for Diffraction Data. ${ }^{89}$
A diode-array Hewlett-Packard HP 8451A spectrophotometer and quartz cells, $1.00 \mathrm{~cm}$ path length, were used in the spectrophotometric measurements. The $\mathrm{pH}$ values were measured with a Corning IA 250 coupled to a Metrohm EA 121 combined glass electrode.

\section{Procedure for $p K_{a}$ determination}

The spectrophotometric method used for $\mathrm{pK}_{\mathrm{a}}$ determination was described earlier. ${ }^{23,90}$ All the spectrophotometric measurements were carried at $25.0 \pm 0.1{ }^{\circ} \mathrm{C}$, using the buffered solution as a blank. Stock HMA-hex solutions $\left(1.0 \times 10^{-2} \mathrm{~mol} \mathrm{dm}^{-3}\right)$ were used in the preparation of working solutions, with concentrations ranging from $3.34 \times 10^{-5}$ to $1.67 \times 10^{-6} \mathrm{~mol} \mathrm{dm}^{-3}$ in $\mathrm{pH} 2.13$ and 8.40. A $1.0 \times 10^{-4} \mathrm{~mol} \mathrm{dm}^{-3}$ HMA-hex solution was used in the determination of the maximum absorption wavelength of the acidic and basic forms, in $\mathrm{pH}$ ranging from 2.78 to 4.10. In order to minimize the decomposition of the compounds, the solutions were prepared directly in the cells, by adding an appropriate volume of the stock solution of HMA-hex to the buffer solution and reaching a final volume of $3.00 \mathrm{dm}^{3}$.

\section{Results and Discussion}

The products are listed in Table 1 and the formulae given are in agreement with elemental analyses and thermogravimetric data. The hex structure is presented in Figure 1. All complexes are anhydrous. The split IR absorption band around $1000 \mathrm{~cm}^{-1}$ indicated that the ligand presents a monodentate behavior in $\mathrm{Cd}(\text { hex })_{2}$ and $\mathrm{Zn}(\text { hex })_{2}$, while a single absorption band in this region suggests a bidentate behavior in $\mathrm{Ni}(\text { hex })_{2}$ and $\mathrm{Cu}(\text { hex })_{2}$, according to Sharma $^{7}$ and Nakamoto. ${ }^{91}$ This is in total agreement with our previous findings for other cyclic DTC complexes with the same metal cations. ${ }^{24,25,90}$

The characteristic $\mathrm{C}-\mathrm{N}$ stretching vibrational mode is observed at $1474-1503 \mathrm{~cm}^{-1}$ and is less intense than that observed for alkyl DTC derivatives due to the low double bond character caused by the rigid ring system. ${ }^{92}$

Table 1. Percentages of metal, carbon, hydrogen and nitrogen found (calculated) and main infrared absorption bands $\left(\mathrm{cm}^{-1}\right)$ for the hexamethylelinedithiocarbamates studied in this work

\begin{tabular}{lcccccc}
\hline Compound(color) & Metal & $\mathrm{C}$ & $\mathrm{H}$ & $\mathrm{N}$ & $v(\mathrm{C}-\mathrm{N})$ & $v(\mathrm{C}-\mathrm{S})$ \\
\hline HMA-hex(white) & - & $56.8(56.9)$ & $9.89(9.55)$ & $9.75(10.2)$ & 1474 & 956,975 \\
$\mathrm{Ni}(\text { hex })_{2}$ (green) & $13.3(14.4)$ & $40.2(41.3)$ & $5.84(5.94)$ & $6.56(6.88)$ & 1503 & 980 \\
$\mathrm{Cu}(\text { hex })_{2}$ (brown) & $14.2(15.4)$ & $41.2(40.8)$ & $5.93(5.87)$ & $6.77(6.80)$ & 1500 & 985 \\
$\mathrm{Zn}(\text { hex })_{2}$ (white) & $15.9(15.8)$ & $41.0(40.6)$ & $5.99(5.84)$ & $6.85(6.77)$ & 1485 & 959,982 \\
$\mathrm{Cd}(\text { hex })_{2}$ (white) & $23.1(24.4)$ & $35.8(36.5)$ & $5.16(5.25)$ & $5.94(6.08)$ & 1485 & 959,979 \\
\hline
\end{tabular}


$p K_{a}$ determination

The use of diode array data for $\mathrm{pK}_{\mathrm{a}}$ determination is convenient, since the decomposition of DTC is very fast in acidic media. ${ }^{19-23}$ The decomposition rate depends on the amine substituents. The procedure considers that the total absorbance at a given wavelength is due to the sum of the absorbances of the protonated (Hhex) and free (hex) forms of the DTC:

$\mathrm{A}_{\mathrm{A}}=\varepsilon_{\mathrm{A}, \mathrm{Hhex}}[$ Hhex $]+\varepsilon_{\mathrm{A}, \mathrm{hex}}[$ hex $]$

$A_{B}=\varepsilon_{B, \text { Hhex }}[$ Hhex $]+\varepsilon_{B, h e x}[$ hex $]$

in which $\mathrm{A}_{\mathrm{A}}$ and $\mathrm{A}_{\mathrm{B}}$ are the absorbances in the wavelengths $\mathrm{A}$ and $\mathrm{B}$, respectively, $\varepsilon_{\mathrm{A}, \text { Hhex }}$ and $\varepsilon_{\mathrm{A} \text {,hex }}$ are the molar absorptivities of the protonated and free forms in the wavelength $\mathrm{A}$, and [Hhex] and [hex] are the concentrations of the protonated and free forms, respectively. The absorptivity coefficients can be obtained from the slopes of A versus [hex] plots, at the maximum wavelengths, in acidic and basic media. On solving equations (1) and (2), it is possible to determine the $[$ hex $] /[$ Hhex $]$ ratio. Then, measuring the absorbances at different $\mathrm{pH}$ values, the $\mathrm{pK}$ can be determined by the Henderson-Hasselbach equation:

$$
\mathrm{pK}_{\mathrm{a}}=\mathrm{pH}-\log \frac{\left[\text { hex }^{-}\right]}{[\text {Hhex }]}
$$

The maximum absorption wavelength of the protonated (Hhex) form was observed at $276 \mathrm{~nm}$. The free form presented two maxima at 260 and $283 \mathrm{~nm}$. For best resolution, $260 \mathrm{~nm}$ (basic, $\varepsilon=1.22 \times 10^{4} \mathrm{~cm}^{-1} \mathrm{~mol} \mathrm{dm}{ }^{-3}$ ) and $276 \mathrm{~nm}$ (acidic, $\varepsilon=$ $1.06 \times 10^{4} \mathrm{~cm}^{-1} \mathrm{~mol} \mathrm{dm}^{-3}$ ) were used in the $\mathrm{pK}$ determination. The results are summarized in Table 2 and a $\mathrm{pK}_{\mathrm{a}}$ value of $3.6 \pm 0.2$ was obtained. Values of $\mathrm{pK}_{\mathrm{a}}$ around 3.29 were previously reported using a conventional spectrophotometric ${ }^{21}$ method at $25{ }^{\circ} \mathrm{C}$ and a $0.01 \mathrm{~mol} \mathrm{dm}{ }^{-3}$ ionic strength.

An evaluation of these differences can be performed considering the changes in spectral shape when the $\mathrm{pH}$ is changed from 2.8 to 4.1 (Figure 2). According to Vandebeek et al., ${ }^{21}$ the acidic form of a DTC presents

Table 2. Results of the $\mathrm{pK}_{\mathrm{a}}$ determination for Hhex $\left(\mathrm{I}=0.50 \mathrm{~mol} \mathrm{dm}^{-3}, 25^{\circ} \mathrm{C}\right)$

\begin{tabular}{lcccc}
\hline $\mathrm{pH}$ & \multicolumn{2}{c}{ absorbance } & [hex]/[Hhex $]$ & $\mathrm{pK}_{\mathrm{a}}$ \\
& $260 \mathrm{~nm}$ & $276 \mathrm{~nm}$ & & \\
\hline 2.78 & 0.445 & 0.713 & 0.246 & 3.41 \\
3.39 & 0.551 & 0.696 & 0.854 & 3.47 \\
4.21 & 0.735 & 0.741 & 3.59 & 3.65 \\
4.79 & 0.819 & 0.778 & 7.35 & 3.93 \\
\cline { 3 - 5 } & & & Mean $\pm \mathrm{sd}^{*}$ & $3.6 \pm 0.2$ \\
\hline
\end{tabular}

$*_{\mathrm{sd}}=$ standard deviation $(\mathrm{n}=4)$. only one peak in the UV region, while the basic form presents two peaks. Figure 2 shows that from $\mathrm{pH} 3.9$ two peaks are clearly observed, evidencing the presence of a significant amount of the basic form. At pH 2.8 only one peak is observed, suggesting the presence of a significant amount of the acidic form.

The results also suggest the following order of acidity for cyclic dithiocarbamate derivatives such as pyrrolidine (pyr), piperidine (pip), morpholine (mor) and hexamethylenedithiocarbamates (hex) (in brackets the $\mathrm{pK}_{\mathrm{a}}$ value and the reference in which it appears):

Hpyr $(3.14)^{23}>\operatorname{Hpip}(3.51)^{23} \approx \operatorname{Hmor}(3.56)^{90} \approx$ Hhex $(3.6)^{\text {this work }}$

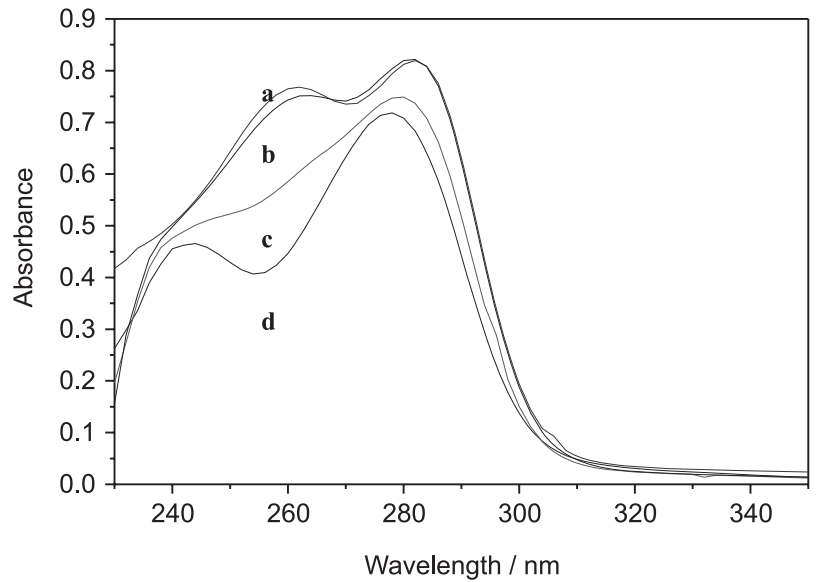

Figure 2. Changes in the UV-Vis spectral shape of a $1.0 \times 10^{-4} \mathrm{~mol} \mathrm{dm}^{-3}$ Hhex solution at different $\mathrm{pH}$ values: a) 4.1, b) 3.9 , c) 3.6 and d) 2.8 .

\section{Decomposition kinetics}

The decomposition of HMA-hex was followed by the absorbance decay of the $286 \mathrm{~nm}$ peak at different $\mathrm{pH}$ values. The $\ln \mathrm{A}_{/} \mathrm{A}_{0}$ versus time plots showed a linear dependence, suggesting a pseudo-first order kinetics with slope equal to $\mathrm{k}_{\mathrm{ap}}$.

Chakrabarty and co-workers ${ }^{19-22}$ investigated the decomposition of dithiocarbamates. According to these authors, the rate of decomposition in basic media is dependent on the $\mathrm{pH}\left(\left[\mathrm{H}^{+}\right]<<\mathrm{K}_{\mathrm{a}}\right)$, but in sufficiently acidic solutions $\left(\left[\mathrm{H}^{+}\right]>>\mathrm{K}_{\mathrm{a}}\right)$ it becomes constant $\left(\mathrm{k}_{\mathrm{ap}} \approx \mathrm{k}_{\mathrm{lim}}\right)$, according to:

$$
\mathrm{k}_{\mathrm{ap}}=\mathrm{k}_{\lim }\left(\frac{\left[\mathrm{H}^{+}\right]}{\left[\mathrm{H}^{+}\right]+\mathrm{K}_{\mathrm{a}}}\right)
$$

in which $k_{a p}$ is the apparent rate constant from the $\ln \mathrm{A} / \mathrm{A}_{0}$ versus time plots, $k_{\text {lim }}$ is the limiting rate constant at low $\mathrm{pH}$ and $K_{a}$ is the acidic dissociation constant.

The results obtained for hex are presented in Table 3 . These data led us to conclude that hex presents an intermediate stability between the analogous 
piperidinedithiocarbamate, pip $\left(\mathrm{t}_{1 / 2 \mathrm{lim}}=10 \mathrm{~s}\right)$ and the 5 membered ring pyrrolidine derivative, pyr $\left(\mathrm{t}_{1 / 2 / \mathrm{lim}}=1620\right.$ s). ${ }^{23}$ Chakrabati and co-workers ${ }^{20,21}$ attributed this difference to the ability of pyr and hex to interact with a water molecule in the decomposition intermediate, due to the configuration of the 5 and 7 membered rings.

The low stability of the anion in acidic medium can explain the large deviations between the measurements in Table 3.

Table 3. HMA-hex decomposition kinetic data at different $\mathrm{pH}$ values and at an ionic strength of $0.50 \mathrm{~mol} \mathrm{dm}^{-3}(\mathrm{KCl})$

\begin{tabular}{|c|c|c|c|c|c|}
\hline $\mathrm{pH}$ & {$\left[\mathrm{H}^{+}\right] /\left(10^{-3} \mathrm{~mol} \mathrm{dm}^{-3}\right)$} & $\mathrm{k}_{\mathrm{ap}} / 10^{-3} \mathrm{~s}^{-1}$ & $\mathrm{t}_{1 / 2} / \mathrm{s}$ & $\mathrm{k}_{\lim } /\left(10^{-2} \mathrm{~s}^{-1}\right)$ & $\mathrm{t}_{1 / 2} \lim / \mathrm{s}$ \\
\hline 2.10 & 7.94 & 62.87 & 11 & 6.48 & 10.7 \\
\hline 2.75 & 1.78 & 1.98 & 350 & 0.225 & 308 \\
\hline 3.98 & 0.105 & 0.770 & 900 & 0.257 & 270 \\
\hline \multirow[t]{2}{*}{4.92} & 0.0120 & 0.880 & 7880 & 1.88 & 36.8 \\
\hline & & & Mean & 2.21 & 156 \\
\hline
\end{tabular}

\section{Thermal decomposition of solid state complexes}

Thermal processes, residues formed, mass losses and temperature ranges observed in each step of the TG/DTG and DSC curves are given in Table 4 under nitrogen and Table 5 under air dynamic atmospheres. Crystalline intermediates were characterized by X-ray diffraction patterns and results were compared with literature data. ${ }^{89}$ TG/DTG and DSC curves are presented in Figure 3 under
$\mathrm{N}_{2}$ and in Figure 4 in air. DSC curves are limited to 600 ${ }^{\circ} \mathrm{C}$ because aluminum pans were used.

As described earlier ${ }^{85}$ the HMA-hex salt showed melting followed by complete volatilization between 110 163 and $90-170{ }^{\circ} \mathrm{C}$ under nitrogen and air dynamic atmospheres respectively (curves not presented). The IR spectra of the HMA-hex salt and of the condensed product confirmed the volatilization phenomena.

Crystalline changes were detected for the copper and the zinc complexes, represented by endothermic peaks in the DSC curves in both atmospheres. Melting points were checked by the use of a capillary tube immerse in a glycerin bath, in order to differentiate them from the crystalline changes. X-ray diffraction analysis was performed in order to characterize the crystalline residues, when available; otherwise the nature of the residues has been assigned by stoichiometric calculations. The results are presented in Table 6 and are compared with literature data. ${ }^{89}$ The thermal behavior of the complexes is discussed below.

\section{Thermal decomposition under nitrogen}

Thermoanalytical curves are presented in Figure 3. According to TG/DTG and DSC data, there is no evidence for the presence of hydration water in the solids. Melting was observed for $\mathrm{Cu}(\text { hex })_{2}, \mathrm{Cd}(\text { hex })_{2}, \mathrm{Ni}(\text { hex })_{2}$ and $\mathrm{Zn}(\mathrm{hex})_{2}$, and it was confirmed in a capillary glass tube

Table 4. Thermal degradation data under nitrogen, from thermogravimetry, showing the thermal process, the interval of temperature ( $\Delta \mathrm{T})$, mass losses $(\Delta \mathrm{m})$ experimental (exp) and calculated (calc), or residue and from differential scanning calorimetry, indicating the temperature of the peak ( $\mathrm{T})$, and the endothermic (endo) or exothermic (exo) nature of the process

\begin{tabular}{|c|c|c|c|c|}
\hline \multirow{2}{*}{$\begin{array}{l}\text { Thermal Process } \\
\left(\mathrm{N}_{2} \text { Atmosphere }\right)\end{array}$} & \multirow{2}{*}{$\begin{array}{c}\Delta \mathrm{T} /{ }^{\circ} \mathrm{C} \\
\text { (TG) }\end{array}$} & \multicolumn{2}{|c|}{$\Delta \mathrm{m}^{\mathrm{a}} / \%$} & \multirow{2}{*}{$\begin{array}{c}\text { DSC Data } \\
\mathrm{T} /{ }^{\circ} \mathrm{C}\end{array}$} \\
\hline & & $\operatorname{Exp}^{b}$ & Calc. & \\
\hline $\mathrm{Cd}(\mathrm{hex})_{2(\mathrm{~s})} \longrightarrow \mathrm{Cd}(\mathrm{hex})_{2(\mathrm{l})}$ & - & - & - & 238.9 (endo) \\
\hline $\mathrm{Cd}(\mathrm{hex})_{2(\mathrm{l})} \longrightarrow \mathrm{CdS}^{\mathrm{c}}+\mathrm{CR}^{\mathrm{d}}$ & $222.8-416.5$ & 39.7 & _- & 312.6 (endo) \\
\hline $\mathrm{CdS}+\mathrm{CR}^{\mathrm{d}} \longrightarrow \mathrm{CdS}$ & $416.5-743,5$ & 30.7 & 31.3 & - \\
\hline $\mathrm{Cu}(\mathrm{hex})_{2(\mathrm{~s} 1)} \longrightarrow \mathrm{Cu}(\mathrm{hex})_{2(\mathrm{~s} 2)}$ & - & - & - & 121.0 (endo) \\
\hline $\mathrm{Cu}(\mathrm{hex})_{2(\mathrm{~s} 2)} \longrightarrow \mathrm{Cu}(\mathrm{hex})_{2(\mathrm{l})}$ & - & - & - & 202.4 (endo) \\
\hline $\mathrm{Cu}(\mathrm{hex})_{2(\mathrm{l})} \longrightarrow \mathrm{Cu}(\mathrm{SCN})_{2}$ & $196.3-283.1$ & 43.6 & 42.8 & 266.4 (endo) \\
\hline $\mathrm{Cu}(\mathrm{SCN})_{2} \longrightarrow \mathrm{CuS}^{\mathrm{c}}$ & $283.1-605.6$ & 23.2 & 23.8 & 407 (ехо) \\
\hline $\mathrm{CuS} \longrightarrow \mathrm{Cu}^{\circ} \mathrm{c}$ & $605.6-864.4$ & 15.4 & 16.9 & - \\
\hline $\mathrm{Ni}(\mathrm{hex})_{2(\mathrm{~s})} \longrightarrow \mathrm{Ni}(\mathrm{hex})_{2(1)}$ & - & - & - & 268.0 (endo) \\
\hline $\mathrm{Ni}(\mathrm{hex})_{2(1)} \longrightarrow 1 / 2 \mathrm{Ni}_{2} \mathrm{~S}_{3}$ & $275.0-400.6$ & 26.2 & 26.2 & 334.5 (endo) \\
\hline $1 / 2 \mathrm{Ni}_{2} \mathrm{~S}_{3} \longrightarrow \mathrm{NiS}$ & $600.3-682.0$ & 22.3 & 22.0 & - \\
\hline $\mathrm{Zn}(\mathrm{hex})_{2(\mathrm{~s} 1)} \longrightarrow \mathrm{Zn}(\mathrm{hex})_{2(\mathrm{~s} 2)}$ & - & - & - & 156.0 (endo) \\
\hline $\mathrm{Zn}(\mathrm{hex})_{2(\mathrm{~s} 2)} \longrightarrow \mathrm{Zn}(\mathrm{hex})_{2(\mathrm{l})}$ & - & - & - & 180,7 (endo) \\
\hline $\mathrm{Zn}(\mathrm{hex})_{2(1)} \longrightarrow \mathrm{ZnS}^{\mathrm{c}}$ & $218.5-386.4$ & 21.5 & 20.8 & 320.4 (endo) \\
\hline $\mathrm{ZnS} \longrightarrow \mathrm{Zn}^{\circ}{ }^{\mathrm{c}}$ & $432.0-735.0$ & 16.0 & 14.4 & - \\
\hline
\end{tabular}

${ }^{a}$ the mass losses refer to the starting material; ${ }^{b}$ relative to residue in relation to the starting material; ${ }^{\mathrm{c}}$ characterized by X-ray diffraction pattern - see Table $6 ;{ }^{\mathrm{d}} \mathrm{CR}=$ carbonaceous residue. 
a)
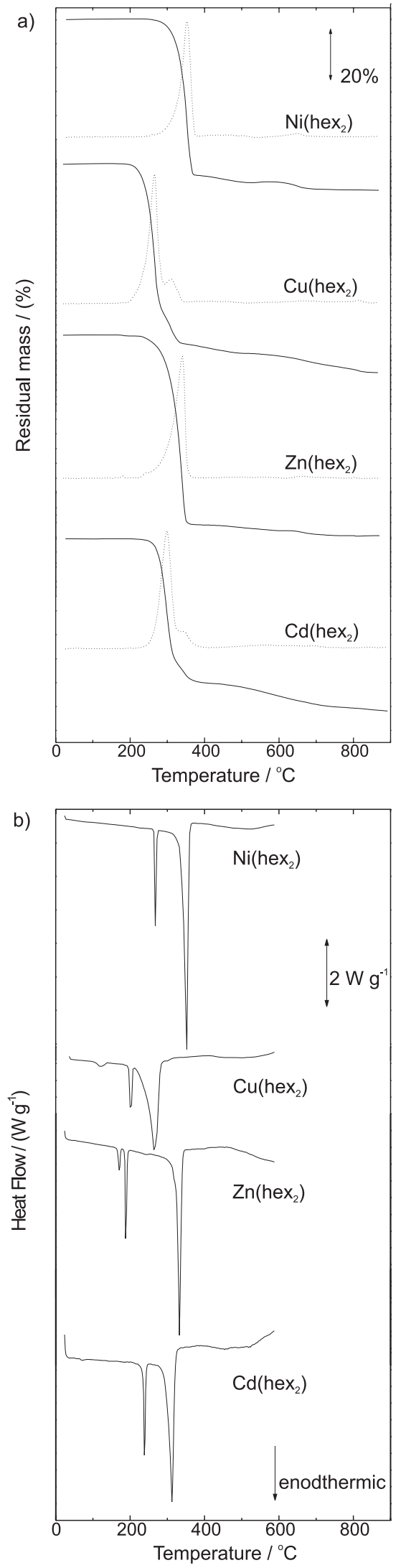

Figure 3. TG (solid)/DTG(dashed) (a) and DSC (b) curves under nitrogen flow of $90 \mathrm{dm}^{3} \mathrm{~min}^{-1}$, sample mass $c a .7 \mathrm{mg}$, heating heat $10{ }^{\circ} \mathrm{C}$ $\mathrm{min}^{-1}$, platinum sample holder (TG/DTG) and aluminum (DSC).
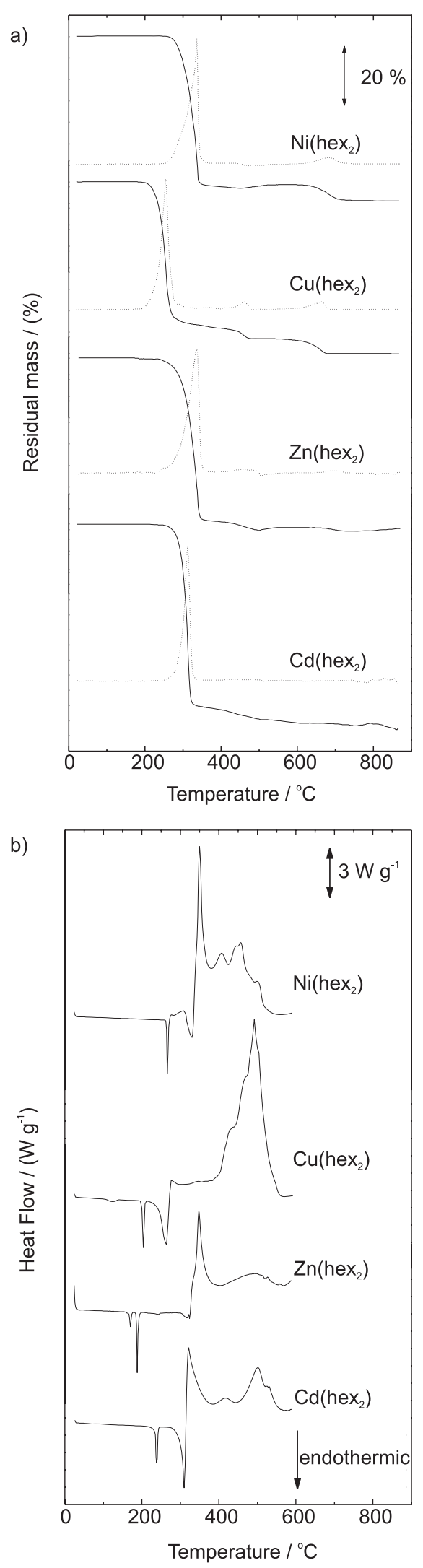

Figure 4. TG (solid)/DTG(dashed) (a) and DSC (b) curves under air flow of $90 \mathrm{dm}^{3} \mathrm{~min}^{-1}$, sample mass $\mathrm{ca} .7 \mathrm{mg}$, heating heat $10{ }^{\circ} \mathrm{C} \mathrm{min}^{-1}$, platinum sample holder (TG/DTG) and aluminum (DSC). 
Table 5. Thermal degradation data under air, from thermogravimetry, showing the thermal process, the interval of temperature $(\Delta \mathrm{T})$, mass losses $(\Delta \mathrm{m})$ experimental (exp) and calculated (calc), or residue and from differential scanning calorimetry, indicating the temperature of the peak (T), and the endothermic (endo) or exothermic (exo) nature of the process

\begin{tabular}{|c|c|c|c|c|}
\hline \multirow{2}{*}{$\begin{array}{l}\text { Thermal Process } \\
\text { (Air Atmosphere) }\end{array}$} & \multirow{2}{*}{$\begin{array}{c}\Delta \mathrm{T} /{ }^{\circ} \mathrm{C} \\
(\mathrm{TG})\end{array}$} & \multicolumn{2}{|c|}{$\Delta \mathrm{m}^{\mathrm{a}} / \%$} & \multirow{2}{*}{$\begin{array}{c}\text { DSC Data } \\
\mathrm{T} /{ }^{\circ} \mathrm{C}\end{array}$} \\
\hline & & Exp. ${ }^{b}$ & Calc. & \\
\hline $\mathrm{Cd}(\text { hex })_{2(s)} \longrightarrow \mathrm{Cd}(\text { hex })_{2(1)}$ & - & - & - & 238.4 (endo) \\
\hline $\mathrm{Cd}(\mathrm{hex})_{2(1)} \longrightarrow \mathrm{CdS}^{\mathrm{c}}$ & $227-617.8$ & 31.3 & 31.2 & $\begin{array}{c}309.6,416.5 \text { (endo) } \\
321.7,501.7 \text { (exo) }\end{array}$ \\
\hline $\mathrm{CdS} \longrightarrow 1 / 2 \mathrm{Cd}_{2} \mathrm{OSO}_{4}$ & $680.0-794.6$ & 34.0 & 36.5 & \\
\hline $1 / 2 \mathrm{Cd}_{2} \mathrm{OSO}_{4} \longrightarrow$ decomposition products & $>800$ & - & - & - \\
\hline $\mathrm{Cu}(\mathrm{hex})_{2(\mathrm{~s} 1)} \longrightarrow \mathrm{Cu}(\mathrm{hex})_{2(\mathrm{~s} 2)}$ & - & - & - & 123.5 (endo) \\
\hline $\mathrm{Cu}(\text { hex })_{2(\mathrm{~s} 2)} \longrightarrow \mathrm{Cu}(\text { hex })_{2(1)}$ & - & - & - & 204.0 (endo) \\
\hline $\mathrm{Cu}(\text { hex })_{2(1)} \longrightarrow 1 / 2 \mathrm{Cu}_{2} \mathrm{~S}(\mathrm{CN})_{2}^{\mathrm{c}}$ & 187.2-387.9 & 32.0 & - & 264.5 (endo) \\
\hline $1 / 2 \mathrm{Cu}_{2} \mathrm{~S}(\mathrm{CN})_{2} \longrightarrow 1 / 2 \mathrm{Cu}_{2} \mathrm{OSO}_{4}$ & $387.9-476.7$ & 27.1 & 29.0 & 492.0 (exo) \\
\hline $1 / 2 \mathrm{Cu}_{2} \mathrm{OSO}_{4} \longrightarrow \mathrm{CuO}^{\mathrm{b}}$ & $568.4-681.3$ & 19.3 & 19.8 & \\
\hline $\mathrm{Ni}(\mathrm{hex})_{2(\mathrm{~s})} \longrightarrow \mathrm{Ni}(\mathrm{hex})_{2(\mathrm{l})}$ & - & - & - & 260.0 (endo) \\
\hline $\mathrm{Ni}(\mathrm{hex})_{2(1)} \longrightarrow 1 / 2 \mathrm{Ni}_{2} \mathrm{~S}_{3}$ & 244.4-430.5 & 26.2 & 28.3 & 308.0 (endo), 349.3 (exo) \\
\hline $1 / 2 \mathrm{Ni}_{2} \mathrm{~S}_{3} \longrightarrow 1 / 2 \mathrm{Ni}_{2} \mathrm{OSO}_{4}$ & $467.6-517.3$ & 28.2 & 29.0 & $407.0,456.3,502.4$ (exo) \\
\hline $1 / 2 \mathrm{Ni}_{2} \mathrm{OSO}_{4} \longrightarrow 1 / 2 \mathrm{Ni}_{2} \mathrm{O}_{3}$ & $621.1-729.5$ & 23.4 & 20.3 & - \\
\hline $\mathrm{Zn}(\mathrm{hex})_{2(\mathrm{~s} 1)} \longrightarrow \mathrm{Zn}(\mathrm{hex})_{2(\mathrm{~s} 2)}$ & - & - & - & 162.4 (endo) \\
\hline $\mathrm{Zn}(\mathrm{hex})_{2(\mathrm{~s} 2)} \longrightarrow \mathrm{Zn}(\mathrm{hex})_{2(\mathrm{l})}$ & - & - & - & 185.0 (endo) \\
\hline $\mathrm{Zn}(\mathrm{hex})_{2(1)} \longrightarrow \mathrm{ZnS}^{\mathrm{c}}$ & $206.5-380.0$ & 23.5 & 22.2 & 316.5 (endo), 348.0 (exo) \\
\hline $\mathrm{ZnS} \longrightarrow \mathrm{ZnO}$ & $390.6-729.5$ & 19.7 & 19.5 & - \\
\hline
\end{tabular}

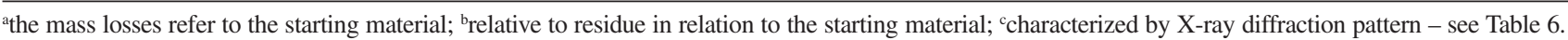

Table 6. X-ray diffraction data for the residues at different temperatures, compared with literature standards ${ }^{\mathrm{a}}$

\begin{tabular}{|c|c|c|c|c|c|c|c|c|c|}
\hline Compound & residue at/standard & & & & & & & & \\
\hline \multirow{6}{*}{ Cd(hex $)_{2}$} & $350^{\circ} \mathrm{C}\left(\mathrm{N}_{2}\right)$ & 3.57 & 3.35 & 3.15 & 2.06 & 1.39 & - & - & - \\
\hline & $\mathrm{CdS}^{\mathrm{a}}$ & 3.58 & 3.36 & 3.16 & 2.07 & 1.39 & - & - & - \\
\hline & $700{ }^{\circ} \mathrm{C}\left(\mathrm{N}_{2}\right)$ & 3.58 & 3.35 & 3.16 & 2.45 & 2.07 & 1.90 & 1.76 & - \\
\hline & $\mathrm{CdS}^{\mathrm{a}}$ & 3.58 & 3.35 & 3.16 & 2.45 & 2.07 & 1.90 & 1.76 & - \\
\hline & $480{ }^{\circ} \mathrm{C}\left(\mathrm{N}_{2}\right)$ & 3.01 & 2.74 & 2.30 & 1.90 & 1.88 & 1.75 & 1.24 & - \\
\hline & $\mathrm{CuS}^{\mathrm{a}}$ & 3.04 & 2.72 & 2.31 & 1.90 & 1.89 & 1.74 & 1.23 & - \\
\hline \multirow{6}{*}{$\mathrm{Cu}(\mathrm{hex})_{2}$} & $850^{\circ} \mathrm{C}\left(\mathrm{N}_{2}\right)$ & 2.08 & 1.28 & 1.08 & 1.06 & - & - & - & - \\
\hline & $\mathrm{Cu}^{\mathrm{a}}$ & 2.08 & 1.28 & 1.09 & 1.04 & - & - & - & - \\
\hline & $330^{\circ} \mathrm{C}$ (air) & 3.24 & 2.85 & - & 1.99 & 1.69 & - & - & - \\
\hline & $\mathrm{Cu}_{2} \mathrm{~S}(\mathrm{CN})_{2}{ }^{\mathrm{a}}$ & 3.18 & 2.88 & 2.30 & 1.97 & 1.70 & - & - & - \\
\hline & $850^{\circ} \mathrm{C}$ (air) & 2.52 & 2.32 & 1.86 & 1.58 & 1.50 & 1.42 & 1.38 & 1.28 \\
\hline & $\mathrm{CuO}^{\mathrm{a}}$ & 2.54 & 2.34 & 1.87 & 1.59 & 1.51 & 1.42 & 1.38 & 1.27 \\
\hline \multirow[t]{2}{*}{$\mathrm{Zn}(\mathrm{hex})_{2}$} & $400^{\circ} \mathrm{C}\left(\mathrm{N}_{2}\right)$ & 3.12 & 2.03 & 1.67 & 1.35 & 1.25 & 1.10 & 1.03 & - \\
\hline & $\mathrm{ZnS}^{\mathrm{a}}$ & 3.12 & 1.91 & 1.63 & 1.35 & 1.24 & 1.10 & 1.04 & - \\
\hline
\end{tabular}

adata from reference 89 .

test. $\mathrm{Zn}(\text { hex })_{2}$ and $\mathrm{Cu}(\text { hex })_{2}$ apparently melted after a crystalline transition, as suggested by the peak shape and the absence of mass loss associated with the process. XRD measurements were not performed before and after the peak in order to confirm these physical changes.

Sulfides were the main residues around $400{ }^{\circ} \mathrm{C}$, after the decomposition of the complexes. Metallic $\mathrm{Cd}, \mathrm{Cu}$ and $\mathrm{Zn}$ were found in the further decomposition steps of the inorganic residue, while NiS remained stable as the final decomposition product in the temperature range investigated.
Only in the $\mathrm{Cu}(\text { hex })_{2}$ case, $\mathrm{Cu}(\mathrm{SCN})_{2}$ was detected as the intermediate in decomposition, as suggested by Sharma. ${ }^{7}$ This is in agreement with previous findings for other cyclic dithiocarbamate derivatives. ${ }^{23-25,90}$

\section{Thermal decomposition in air}

The thermoanalytical curves recorded in air are presented in Figure 4. For $\mathrm{Cd}, \mathrm{Ni}$ and $\mathrm{Zn}$ complexes, the respective sulfides were produced after the first 
decomposition step and were converted to oxide ( $\mathrm{Zn}$ ) or oxysulfates $(\mathrm{Cd}$ and $\mathrm{Ni}$ ) by further heating of the residue (see Table 5). The detection of oxysulfates as decomposition intermediates is in agreement with previous results. ${ }^{24}$ The copper complex decomposed in a different way, generating $\mathrm{Cu}_{2} \mathrm{~S}(\mathrm{CN})_{2}$, oxysulfate and finally the oxide, according to the X-ray diffraction patterns of the residues ${ }^{89}$ Crystalline changes and melting processes were also observed, in agreement with the data obtained under $\mathrm{N}_{2}$ and reported in the previous section.

Results indicated that the following stability order can be established, according to the temperature in which decomposition starts: $\mathrm{Ni}(\text { hex })_{2}>\mathrm{Cd}(\text { hex })_{2}>\mathrm{Zn}(\text { hex })_{2}>$ $\mathrm{Cu}(\mathrm{hex})_{2}$.

\section{Conclusions}

The Hhex is the weaker acid when compared to the series of cyclic DTC derived from pyrrolidine, piperidine and hexamethyleneamine, respectively 5, 6 and 7-membered aminic rings. The limiting half life $\left(\mathrm{t}_{1 / 2 \mathrm{lim}}\right)$ suggests that hex is more stable than piperidinedithiocarbamate (pip) and morpholinedithiocarbamate (mor) and much less stable than pyrrolidinedithiocarbamate (pyr). ${ }^{23,90}$

The thermal analytical studies revealed that sulfides were the main residues obtained under nitrogen atmosphere, which were reduced to the elementary metals in the case of the copper(II) and zinc(II) complexes. Oxysulfates were observed in air as intermediates of the decomposition of $\mathrm{Ni}(\text { hex })_{2}, \mathrm{Cu}(\text { hex })_{2}$ and $\mathrm{Cd}(\text { hex })_{2}$, while oxides were obtained as final decomposition products. The nickel(II) complex was the most stable in this series.

\section{References}

1. Kitson, T.; Education in Chemistry 1985, 43.

2. Rabbi, M.F.; Finnegan, A.; Al-Hartli, L.; Stong, S.; Roebuck K.A.; Journal of Acquired Immune Deficiency Syndromes and Human Retrovirology 1998, 19, 321.

3. Topping, R.M.; Jones, M.M.; Med. Hipothesys 1989, $27,55$.

4. Weuffen, A.; Kewitsch, A.; Arch. Exp. Veterinaermed. 1967, 21, 1049.

5. Powell, A.K.; Brit. J. Cancer 1954, 8, 529.

6. Hill, J. O.; Chirawongaram, S.; J. Thermal Anal. 1994, 41, 511.

7. Sharma, A.K.; Thermochim. Acta 1986, 104, 339.

8. Magee, R.J.; Hill, J.O.; Rev. Anal. Chem. 1985, 8, 5.

9. Bond, A.M.; Martin, R.L.; Coord. Chem. Rev. 1984, 54, 23.

10. Sengupta, S.K.; Kumar, S.; Termochim. Acta 1984, 72, 349.

11. Hill, J.O.; Magee, R.J.; Rev. Inorg. Chem. 1981, 3, 141.

12. Coucovanis, D.; Progr. Inorg. Chem. 1979, 26, 301.
13. Coucovanis, D.; Progr. Inorg. Chem. 1970, 11, 233.

14. Hulanicki, A.; Talanta 1967, 14, 1371.

15. Thorn, G.D.; Ludwig, R.A.; The Dithiocarbamates and Related Compounds, Elsevier: Amsterdam, 1962.

16. Castro, E.A.; Cortes, R.; Santos, J.G.; Vega, J.C.; J. Org. Chem. 1982, 47, 3774.

17. De-Filippo, D.; Deplano, P.; Devillanova, F.; Trogu, E.F.; Verani G.; J. Org. Chem. 1973, 38, 560.

18. Usatenko, Y.I.; Barkalov, U.S.; Tulypa, F.M.; J. Anal. Chem.USSR. 1970, 25, 1458.

19. Aspila, K.I.; Chakrabarti, C.L.; Sastri, V.S.; Anal. Chem. 1973, 45,363 .

20. Joris, S.J.; Aspila, K.I.; Chakrabarti, C.L.; J. Phys. Chem. 1970, 74, 860 .

21. Vandebeek, R.R.; Joris, S.J.; Aspila, K.I.; Chakrabarti, C.L.; Can. J. Chem. 1970, 48, 2204.

22. Aspila, K.I.; Sastri, V.S.; Chakrabarti, C.L.; Talanta 1969, 16, 1099.

23. Cavalheiro, E.T.G.; Chierice, G.O.; J. Braz. Chem. Soc. 1997, $8,53$.

24. Cavalheiro, E.T.G.; Ionashiro, M.; Marino, G.; Breviglieri, S.T.; Chierice, G.O.; J. Braz. Chem. Soc. 1999, 10, 65.

25. Cavalheiro, E.T.G.; Ionashiro, M.; Marino, G.; Breviglieri, S.T.; Chierice, G.O.; Transit. Metal Chem. 2000, 25, 69.

26. Bundalevska, J.M.; Koyuncu, I.; Ay, O., Cundeva; K.; Akcin, G.; Stafilov, T.; J. Environ. Sci. Health, Part A: Toxic/Hazard. Subst. Environ. Eng. 2005, 40, 1045.

27. Kojuncu, Y.; Bundalevska, J.M.; Ay, U.; Cundeva; K.; Stafilov, T.; Akcin, G.; Sep. Sci. Technol. 2004, 39, 2751.

28. Ay, U.; Cundeva; K.; Stafilov, T.; Zajkova, V.P.; Pavlovska, G.; Anal. Lett. 2004, 37, 695.

29. Cundeva; K.; Stafilov, T.; Pavlovska, G.; Karadjova, I.; Arpadjan, S.; Int. J. Environ. Anal. Chem. 2003, 83, 1009.

30. Pavlovska, G.; Cundeva; K.; Stafilov, T.; Zendelovska, D.; Sep. Sci. Technol. 2003, 38, 1111.

31. Pavlovska, G.; Cundeva; K.; Stafilov, T.; Anal. Lett. 2002, 35, 2347.

32. Pavlovska, G.; Stafilov, T.; Cundeva; K.; Fresenius. J. Anal. Chem. 2001, 369, 670.

33. Stafilov, T.; Cundeva; K.; Pavlovska, G.; Int. J. Environ. Anal. Chem. 2001, 80, 269.

34. Stafilov, T.; Pavlovska, G.; Cundeva; K.; Zendelovska, D.; Paneva, V.; J. Environ. Sci. Health, Part A: Toxic/Hazard. Subst. Environ. Eng. 2001, 360, 735.

35. Zendelovska, D.; Pavlovska, G.; Cundeva; K.; Stafilov, T.; Talanta 2001, 54, 139.

36. Zendelovska, D.; Cundeva; K.; Stafilov, T.; Mikrochim. Acta 2000, 135, 55.

37. Cundeva; K.; Stafilov, T.; Pavlovska, G.; Microchem. J. 2000, $65,165$.

38. Stafilov, T.; Zendelovska, D.; Pavlovska, G.; Cundeva; K.; Spectrochim. Acta, Part B 2002, 57, 907. 
39. Pavlovska, G.; Cundeva; K.; Stafilov, T.; Croatia Chemica Acta 2001, 74, 121.

40. Stafilov, T.; Pavlovska, G.; Cundeva; K.; Turk. J. Chem. 2000, 24, 303.

41. Stafilov, T.; Pavlovska, G.; Cundeva; K.; Michrochem. J. 1998, $60,32$.

42. Pavlovska, G.; Stafilov, T.; Cundeva; K.; Fresenius. J. Anal. Chem. 1998, 361, 213.

43. Paneva, V.Z.; Cundeva; K.; Stafilov, T.; Spectrochim. Acta, Part B 2005, 60, 403.

44. Cundeva; K.; Pavlovska, G.; Stafilov, T.; J. Serb. Chem. Soc. 2001, 66, 709.

45. Pavlovska, G.; Cundeva; K.; Stafilov, T.; Sep. Sci. Technol. 2000, 35, 2663.

46. Cundeva; K.; Stafilov, T.; Pavlovska, G.; Spectrochim. Acta, Part B 2000, 55, 1081.

47. Ichinoki, S.; Okamoto, Y.; Ishikuma, H.; Fujii, Y.; J. Liq. Chromatogr. Relat. Technol. 2003, 26, 2797.

48. Shijo, Y.; Yoshida, H.; Kitamura, T.; Yoshimoto, E.; Uehara, N.; Anal. Sci. 1996, 12, 761.

49. Ichinoki, S.; Yamazaki, M.; Omura, M.; Nagai, R.; Bunseki Kagaku 1996, 45, 837.

50. Falter, R.;Scholer, H.F.; Fresenius J. Anal. Chem. 1995, 353, 34.

51. Ichinoki, S.; Yamazaki, M.; J. Chromatogr. Sci. 1991, $29,184$.

52. Ichinoki, S.; Yamazaki, M.; Anal. Chem. 1985, 57, 662.

53. Frigge, C.; Jackwerth, E.; Anal. Chim. Acta 1993, 271, 299.

54. Buhler, A.; Jackwerth, E.; Fresenius J. Anal. Chem. 1992, 343, 362.

55. Fang, Z.L.; Dong, L.P.; J. Anal. At. Spectrom. 1992, 7, 439.

56. Fang, Z.L.; Sperling, M.; Welz, B.; J. Anal. At. Spectrom. 1991, 6, 301 .

57. Frigge, C.; Jackwerth, E.; Anal. Chim. Acta 1991, 242, 99.

58. Byrko, V.M.; Vizhenskii, V.A.; Molchanova, T.P.; J. Anal. Chem. USSR 1987, 42, 251.

59. Yamamoto, Y.; Nishino, Y.; Ueda, K.; Talanta 1985, 32, 662.

60. Yamamoto, Y.; Sugita, M.; Ueda, K.; Bull. Chem. Soc. Jpn. 1982, 55, 742.

61. Tokahoglu, S.; Kartal, S.; Elci L.; Bull Kor. Chem. Soc. 2002, 23, 693.

62. Alexandrova, A.; Arpadjan, S.; Anal. Chim. Acta 1995, 307, 71.

63. Alexandrova, A.; Arpadjan, S.; Analyst 1993, 118, 1309.

64. Wommel, S.; Calmano, W.; Acta Hydrochimica et Hydrobiologica 1992, 265.

65. Dapaah, A.R.K.; Takano, N.; Ayame, A.; Anal. Chim. Acta 1999, 386, 281.

66. Dapaah, A.R.K.; Ayame, A.; Anal. Chim. Acta 1998, 360, 26.

67. Dapaah, A.R.K.; Ayame, A.; Anal. Sci. 1997, 13, 405.

68. Miyazake, A.; Sampei, T.; Tao, H.; Nagase, T.; Nippon Kagaku Kaishi 1992, 307.

69. Tao, H.; Miyazake, A.; Bamsho, K.; Unezaki, Y.; Anal. Chim. Acta 1984, 156, 159.
70. Tsalev, D.L.; Petrova, V.P.; Dokladi Na Bolgarskata Akademiya Na Naukite 1979, 32, 911.

71. Dornemann, A.; Kleist, H.; Analyst 1979, 104, 1030.

72. Tsalev, D.L.; Dokladi Na Bolgarskata Akademiya Na Naukite 1979, 32, 779.

73. Berndt, H.; Jackwerth, E.; Fresenius J. Anal. Chem. 1978, 290, 369.

74. Busev, A.I.; Tereshchenko, A.P.; Naidina, V.P.; J. Anal. Chem. USSR 1976, 31, 944.

75. Busev, A.I.; Byrko, V.N.; Tereshchenko, A.P.; Novikova, N.N.; Naidina, V.P.; Terentev, P.B.; Zhurnal Analiticheskoi Khimii 1970, 25, 665 .

76. Alekseev, T.A.; Tresvyat, P.A.; Treshch, A.P.; Russ. J. Phys. Chem. 1971, 45, 1669.

77. Yamase, T.; Kokado, H.; Inoue, E.; Bull. Chem. Soc. Jpn. 1972, 45, 726.

78. Yamase, T.; Kokado, H.; Inoue, E.; Bull. Chem. Soc. Jpn. 1970, 43, 669.

79. Yamase, T.; Kokado, H.; Inoue, E.; Bull. Chem. Soc. Jpn. 1970, 43, 934.

80. Zvonkova, Z.V.; Yakovenk, V.I.; Soviet Physics Crystalography 1968, 13, 134.

81. Zvonkova, Z.V.; Poveteva, Z.P.; Vozzenni, V.M.; Gluskova, V.P.; Jakovenk, V.I.; Khvatkin, A.N.; Acta Crystallographica S 1966, 21, A155 Part 7S.

82. Pavlicek, M.; Travnicek, Z.; Pastorek, R.; Marek, J.; Transition Met. Chem. (Dordrecht, Neth.) 2003, 28, 260.

83. Dahiya, K.K.; Kaushik, N.K.; Thermochim. Acta 1989, 141, 69.

84. Dahiya, K.K.; Kaushik, N.K.; Indian J. Chem., Sect. A: Inorg., Bio-inorg., Phys., Theor. Anal. Chem. 1988, 27, 449.

85. Ramos, L.A.; Cavalheiro, E.T.G.; Chierice, G.O.; J. Therm. Anal. Calorim. 2005, 79, 349.

86. Roussel-Uclaf (ROUS); FR2081589-A5; FR2081589-A, 1970 (AN 1972: 501408)

87. Elving, P.J., Morkowitz, J.M.; Rosenthal, I.; Anal. Chem. 1956, 28, 1179.

88. Cavalheiro, E.T.G.; Plepis, A.M.G.; Chierice, G.O.; Neves, E.F.A.; Polyhedron 1987, 9, 1717.

89. International Centre for Diffraction Data. Power Diffraction File (CD-ROM). Newton Square, ICDD, 1994.

90. Antunes, P.A.; Breviglieri, S.T.; Chierice, G.O.; Cavalheiro, E.T.G.; J. Braz. Chem. Soc. 2001, 12, 473.

91. Nakamoto, K.; Infrared and Raman Spectra of Inorganic and Coordination Compounds, $3^{\text {rd }}$ ed.; John Wiley: New York, 1977.

92. Preti, C.; Tosi, G.; Zanini, P.; J. Mol. Struct. 1979, 53, 35.

Received: September 19, 2005 Published on the web: May 16, 2006

FAPESP helped in meeting the publication costs of this article. 